\title{
Integrating general and local context-dependent factors into a framework for analysing business sectors in Bottom-of-the-Pyramid emerging markets
}

\author{
Maaike Maren BROEKSMA, Bart Jan Willem (Bartjan) PENNINK \\ University of Groningen, The Netherlands
}

Received: 16.03.2021, Revised: 29.05.2021, Accepted: 13.06.2021 doi: http://dx.doi.org/10.29015/cerem.913

\begin{abstract}
:
Aim: This paper investigates how a framework for analysing business sectors in emerging markets looks like when taking into account the local context-dependent and general factors of The Bottom-ofthe-Pyramid (BoP). The BoP segment in emerging markets represents a major growth potential for firms, including multinational enterprises (MNEs) from developed countries. However, the continued lack of success of MNEs in these markets has shown that generic one-size-fits-all strategies for the BoP are not appropriate as BoP contexts differ between countries.
\end{abstract}

Design / Research methods: The sample that was selected for the research includes two nongovernmental organizations (NGOs) related to the BoP and eight managers at MNEs with activities in the BoP, which have been interviewed in a semi-structured manner to collect rich data. Also, an additional analysis, BoP-orientation, and further extensions to the original analyses are being presented.

Conclusion / findings: The study results in an advanced framework for analysing business sectors in emerging markets.

Originality / value of the article: Current frameworks for analysing business sectors in emerging markets do take into account inter-country differences but fail to recognize intra-country differences, which causes them to fall short on their applicability to the BoP. This paper fills the gap how frameworks for analysing business sectors in emerging markets can be made applicable for the BoP by taking into account both the local context-dependent and general factors of a BoP-market to analyse it for opportunities, threats, and eventually and strategic entry mode.

Keywords: Bottom-of-the-Pyramid (BoP), multinational enterprises (MNEs), emerging markets, market entry, business sector analysis, context dependency.

JEL: F63, L11, I30, O12

Correspondence address: Dr. Bartjan W. Pennink, University of Groningen, Faculty of Economics and Business, Global Economics and Business, Nettelbosje 2, 9747 AE Groningen, The Netherlands. E-mail: b.j.w.pennink@rug.nl 


\section{Maaike Maren BROEKSMA, Bart Jan Willem (Bartjan) PENNINK}

\section{Introduction}

Since the mid-1970s, multinational enterprises (MNEs) have been moving from developed countries towards emerging markets (EMs) due to the saturation of the developed markets and the possibility of new market opportunities and future growth (London, Hart 2004). These EMs differ significantly from the traditionally served developed markets, and it was recognized that new strategies for entering these markets were necessary (Marquis, Raynard 2015; Narayanan, Fahey 2005). Consequently, researchers started to focus on how to analyse and enter business sectors in EMs. However, the majority of previous research on business activities in EMs do not distinguish between the developed and underdeveloped segments of these countries, neglecting the large internal diversities and considering EMs as homogeneous entities (Schuster, Holtbrügge 2012). The so-called "Bottom-of-thePyramid" (BoP) has to be separated from the more traditional markets at the "Topof-the-Pyramid" (ToP) within a country as they have significantly different socioeconomic, cultural and infrastructural contexts (see figure 1). MNEs therefore require different strategies for different types of markets within an EM (Omar, Williams 2009; London, Hart 2004; Schuster, Holtbrügge 2012). The frameworks are currently only applicable to the ToP segment of EMs and do not include the possibility of intra-national differences. Therefore, this research focuses on how the frameworks can be developed further to make them also applicable to the BoP.

For MNEs expanding towards EMs, the common choice is to serve the ToP, while for a long time BoP-markets, consisting of the world's lowest-income population, have been turned down and overlooked as a potential target. However, since the publications by Prahalad and colleagues from 1998 on (e.g. Prahalad, Lieberthal 1998; Prahalad, Hart 2002) the idea that MNEs could both enhance their profit and reduce the poverty of billions of people by selling to the poor has been widespread (Kolk et al. 2014). According to Prahalad, the BoP is a significant untapped global market and their aggregated income represents a major potential for new growth paths for MNEs (Zhu et al. 2019). However, many firms that entered this market struggled for success, resulting in eventually pulling their projects out of the BoP or moving them to their corporate social responsibility (CSR) branch (Chliova, Ringov 2017). When MNEs move to EMs, they often misinterpret it as a 
strategy for the BoP (Landrum 2014). The traditional internationalization strategy that was developed for foreign direct investment (FDI) towards the one billion people in ToP is not sufficient to be simply adapted and extended into BoP-markets due to the large differences in these markets including their socio-economic development, culture and accessibility (Schuster, Holtbrügge 2012; Wright et al. 2005). Instead, corporations have to rethink and reshape the way they operate their businesses to fit with the context of the BoP (London, Hart 2010).

Researchers began to explore and present business models modified to the BoP (e.g. Ver Loren van Themaat et al. 2013) and frameworks for specifically analysing BoP business models (e.g. Raj, Aithal 2018). However, to the best of my knowledge a framework for analysing business sectors in EMs that also can be applied to the BoP segment within these markets has not been presented yet. In studies that focus on MNE strategies for the BoP, the specific local factors that are context-dependent are not separated from general BoP characteristics and the BoP has often been depicted as a homogeneous segment (Lappeman et al. 2018). Hitherto, mostly 'onesize-fits-all' business models and strategies for the BoP have been presented in academic studies. However, as illustrated in figure 1 "the $\mathrm{BoP}$ is not homogeneous both within and across communities" (Dembek et al. 2020: 380), and especially in BoP-markets a one-size-fits-all strategy will not work and leads to entry failures (Lappeman et al. 2018). One-size-fits-all strategies are significantly different from strategies that are composed based on frameworks since frameworks take into account local contextual differences between countries in which the BoP is situated, and one-size-fits-all strategies do not. Lappeman et al. (2018) are among the first to evaluate both the general characteristics that are true for every BoP-market and those that are local and thus context-specific. This research builds on these ideas by considering both those characteristics from the BoP that differ per context and that are generally present in every BoP-market. 


\section{Figure 1. Differences between BoP \& ToP within country and BoP \& BoP between countries}

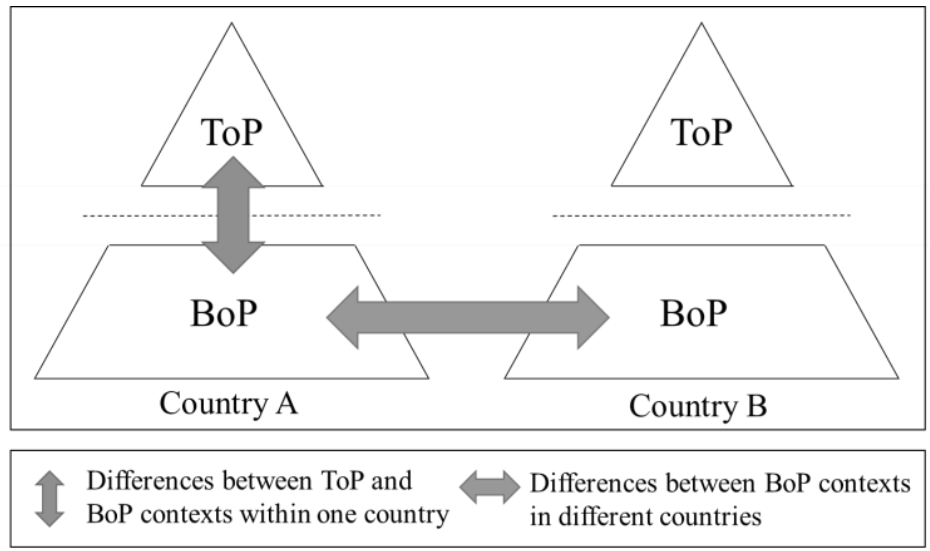

Source: authors' own elaboration.

When developing a strategy for the BoP, MNEs have to take into account both the differences between the ToP and BoP context within a country and the local differences of $\mathrm{BoP}$ contexts between different countries. Therefore, a framework that considers both the local and general factors of a BoP-market to analysis it for opportunities and threats, and eventually choosing a strategic entry mode is needed. Existing frameworks for analysing business sectors in emerging markets (e.g. Van den Ban 2009; Quist 2011) fail to include the possibility of a BoP-segment and that this $\mathrm{BoP}$ can differ between countries. This forms the theoretical gap for this research. Entry mode was chosen as a research subject because it can be perceived as one of the most critical decisions a firm must make when it enters a foreign market (Cui, Jiang 2012). It is thus critical for MNEs to make informed choices in developing their strategy for entering a specific BoP-market. Building on the frameworks that were presented in the work of van den Ban (2009) and Quist (2011) for analysing business sectors in EMs, this article investigates to which extent they are applicable in the context of the $\mathrm{BoP}$ and which factors and theories have to be changed or added.

Therefore, the following research question arises: "How does a framework for analysing business sectors in emerging markets look like when taking into account the local context-dependent and general factors of the BoP?" 


\section{Literature review}

\subsection{Existing frameworks for analysing emerging markets business sectors}

Before the decision is made whether to engage in FDI in a particular new market, firms first have to analyse and gain knowledge on this new environment. Especially EMs, characterized by greater informality, less developed governments and weaker political, legal and socio-cultural environments, can significantly differ from developed countries (Marquis, Raynard 2015), making a thorough understanding of these environments critical. As many theories for analysing markets and business sectors are designed for developed market economies, Van de Ban (2009) developed a framework for analysing business sectors in EMs to evaluate whether a particular business sector in an EM is attractive to enter, and Quist (2011) developed this framework further (see figure 2). The framework, depicted in figure 2, will be discussed briefly in paragraphs 2.1.1.-2.1.4.

\subsubsection{Institutional analysis}

Institutions, "the rules of the game in a society, [...] the humanly devised constraints that shape human interaction" (North 1990: 3), can be classified in formal rules and informal constraints within a society. Formal institutions are the rules that are formally enforced by state bodies on a society and are reflected in laws, regulations and property rights (Estrin, Prevezer 2011). While some debate is going on about the conceptualization of informal institutions, a widely accepted definition comes from North (2005), viewing them as restraints people impose on themselves and can be found in shared norms, values and beliefs. Informal institutions are commonly measured in terms of the cultural characteristics that form the shared behaviour within a society (Orcos et al. 2018). The quality of institutions can differ between markets. A country has institutional voids when it lacks formal institutions, such as property rights protection, enforcement of the law and corruption is present. To analyse the institutional context Whitley's Business Systems (1999) Hall and Soskice's varieties of capitalism (2003) are suggested as useful tools in academic literature. 
Maaike Maren BROEKSMA, Bart Jan Willem (Bartjan) PENNINK

Figure 2. Framework for analysing business sectors in emerging markets

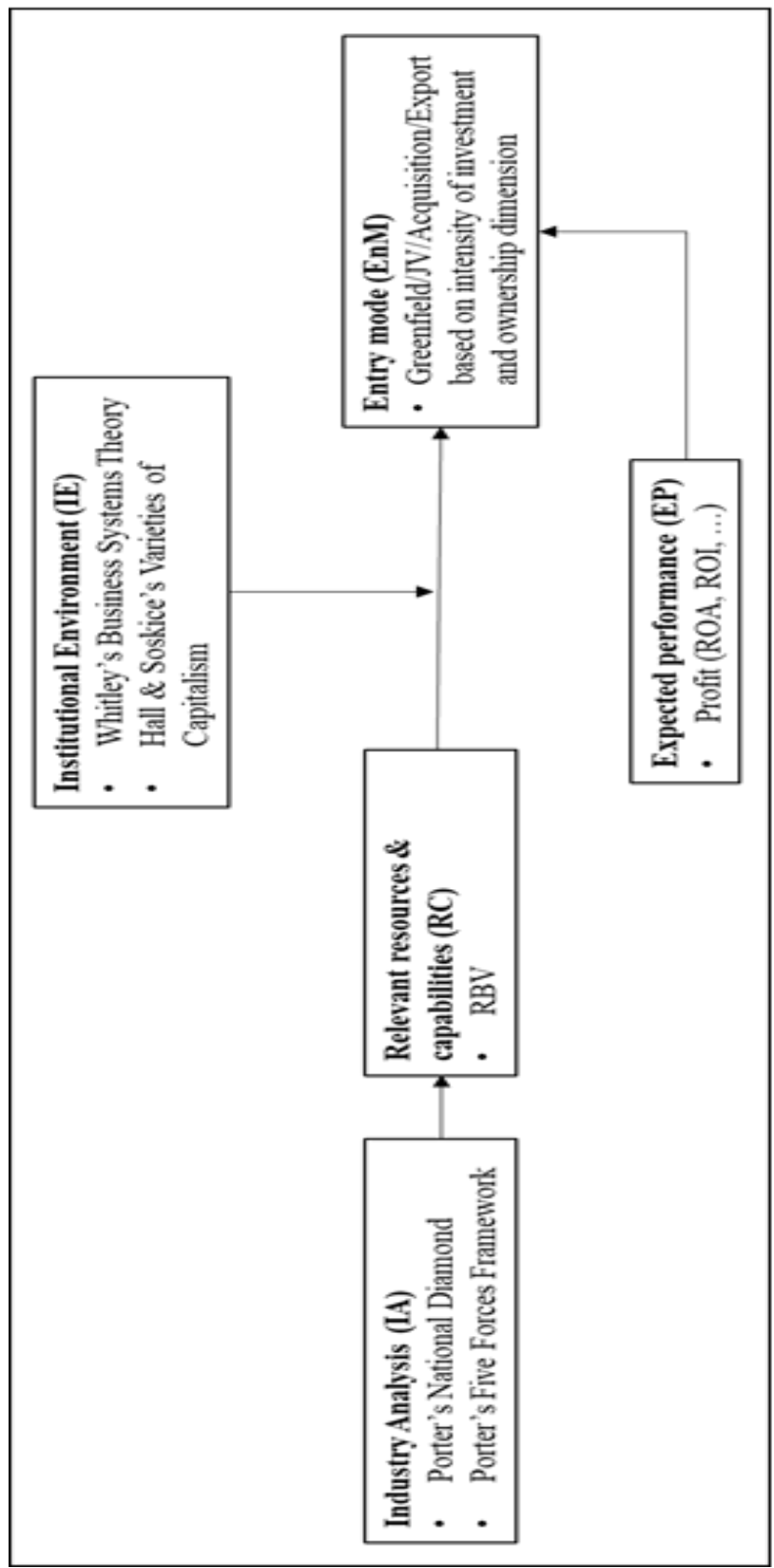

Source: Van den Ban (2009) with further developments from Quist (2011). 


\section{Whitley's (1999) Business Systems theory}

Whitley (1999) argues that individual countries develop distinctive business systems on a national level and that these systems can be classified and characterized through patterns of economic coordination and control in market economies. When a firm performs FDI in a new market, it is obliged to respond to that a nation's specific patterns of economic coordination. The business systems theory explains why firms have different types of behaviour in different countries. Through the analysis of economic activity coordination and governmental factors, international differences of businesses and their behaviour can be explained (Lundvall 1999). By identifying a nation's business system, MNEs that pursue to enter an EM can acquire important knowledge about that country as all firms have to deal with a nation's unique patterns of economic coordination. The national business system exists out of specific institutional characteristics that correspond to the economic performance of a certain country, such as the role of the government and the relationship and trust with them, the functionality of financial control systems and the extent of development of skills (Jamali, Karam 2016). The dominance of certain business-system types and their specific strategies and relations reflect the business system characteristics (Hotho 2014).

\section{Hall \& Soskice's Varieties of Capitalism (2003)}

Like Whitley's business systems (1999), Hall and Soskice's Varieties of Capitalism (2003) is a tool to compare national economies based on how they are institutionally arranged in order to explain why cross-national differences exist. Hall and Soskice (2003) distinguish between coordinated market economies (CMEs) and liberal market economies (LMEs) as two distinct ways of organizing capitalism. In CMEs, firms attain sustainable competitive advantage through their human assets and institutional coordination. Firms and other institutions such as the government aspire to develop strategic interaction and collective mechanisms for organizations to strengthen the national competitive position. In LMEs companies attempt to gain competitive advantage through competing on a basis of low-skilled and low-wage workers. 
Since there is less high-skilled labour in these models, the need for firms to have strategic cooperation with other institutions to gain competitive advantage is less than in CMEs (Wilkins et al. 2010). Hall and Soskice (2003) argue that the level of support in a country for certain kinds of coordination depends on that country's institutional environment, and analysing this can be helpful for firms. By identifying a nation's market structure, the prediction of strategic corporate behaviour is possible (Wilkins et al. 2010).

\subsubsection{Industry analysis}

To analyse opportunities and risks in a certain industry on a national level, Porter's National Diamond (1990) and Porter's Five Forces can be utilized. The opportunities and risks that are identified in this analysis are only based on external factors, and thus are the same for every MNE that wants to enter a specific market.

\section{Porter's (1990) National Diamond}

Porter's (1990) national diamond (figure 3) is a tool to assess a country's competitive advantage and explains why some countries are succeeding more in particular industries than in others. Porter argues that some national environments are more supportive of competitive success than others. The knowledge that firms can derive by assessing these factors can assist them in (re-) shaping their strategy and in turn help them to become increasingly competitive.

Porter distinguishes between the four attributes that interdependently shape a country's competitive advantage: factor conditions, demand conditions, related and supporting industries, and firms strategy, structure and rivalry (Porter 1990). Additionally, Porter (1990) describes that the four main elements that form the diamond are affected by two supplementary external elements, i.e. government and chance (Vlados 2019). 


\section{Figure 3. Porter's National Diamond}

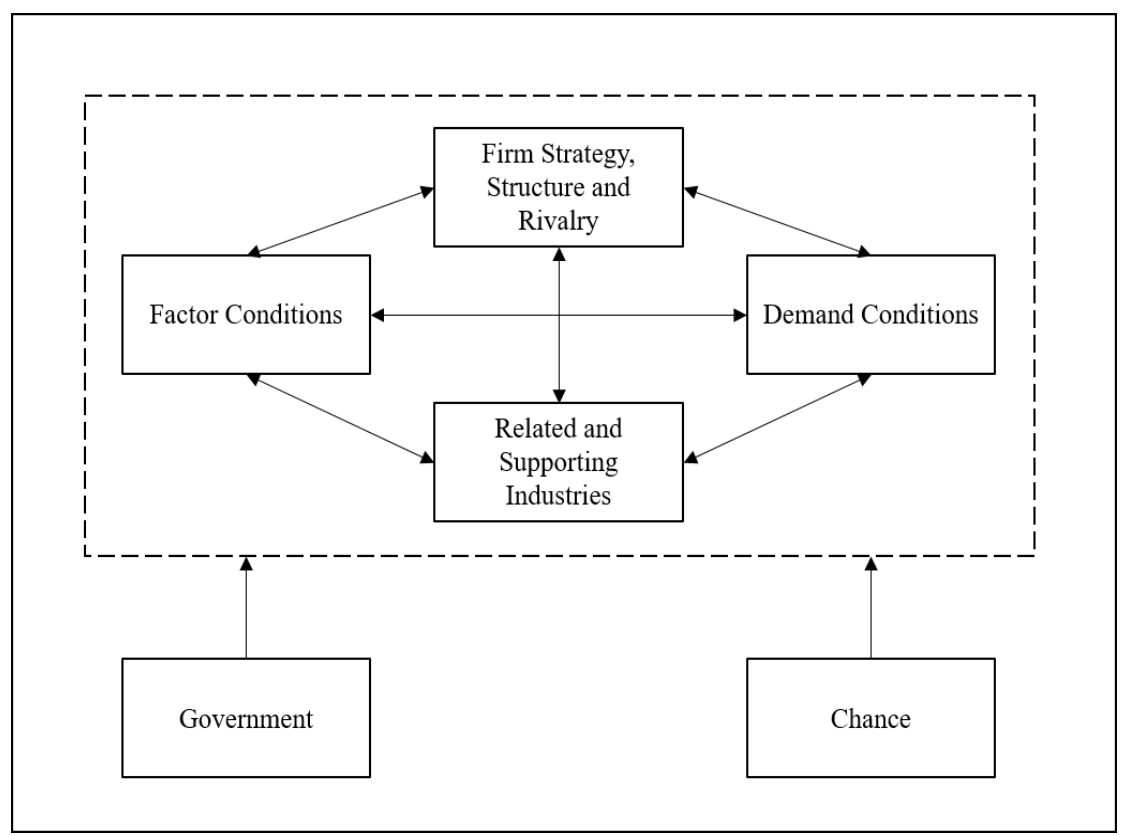

Source: Porter (1990).

\section{Porter's (2008) Five Forces}

Porter's Five Forces Framework (FFF) (2008) can be used to assess an industry's attractiveness by identifying the economic forces that shape competition in an industry, consisting of three main sets of components: bargaining power of buyers and bargaining power of suppliers; threat of new entrants and threat of substitutes; and the rivalry among existing competitors that influences entry and growth. Porter separates bargaining power and the extended rivalry, making his model consist out of five forces (figure 4) on which an industry's attractiveness for investment depends (Narayanan, Fahey 2005). Porter argues that when the five competitive forces and their underlying causes are understood, the sources for profitability and competitive advantage in a certain industry can be unravelled. Additionally, Porter (2008) suggests that by understanding the competitive landscape thoroughly, i.e. beyond existing rivals, opportunities in terms of customers, suppliers, substitutes, potential entrants and rivals can be uncovered. 


\subsubsection{Relevant resources and capabilities}

The resource-based view of the firm

A firm has a collection of resources and capabilities that attain competitive advantage (Becerra 2009). By looking at the firm's internal sources of sustained competitive advantage, the resource-based view (RBV) attempts to explain why firm performance varies within the same industry (Kraaijenbrink et al. 2010). Barney (1991) argues that firms need a sustained competitive performance, which can be achieved through acquiring and controlling resources and capabilities. Furthermore, he argues that resources have to be Valuable, Rare, Inimitable and Non-substitutable (VRIN) to offer sustainable competitive advantage to the firm. A valuable resource helps a firm to decrease costs while increasing their revenues. Rare resources are those that are not owned by every firm. Resources should be very difficult to imitate or replicate. If a resource is not easily substituted by another type of resource, it can help a firm to achieve sustained competitive advantage (Becerra 2009).

\section{Figure 4. Porter's Five Forces Framework}

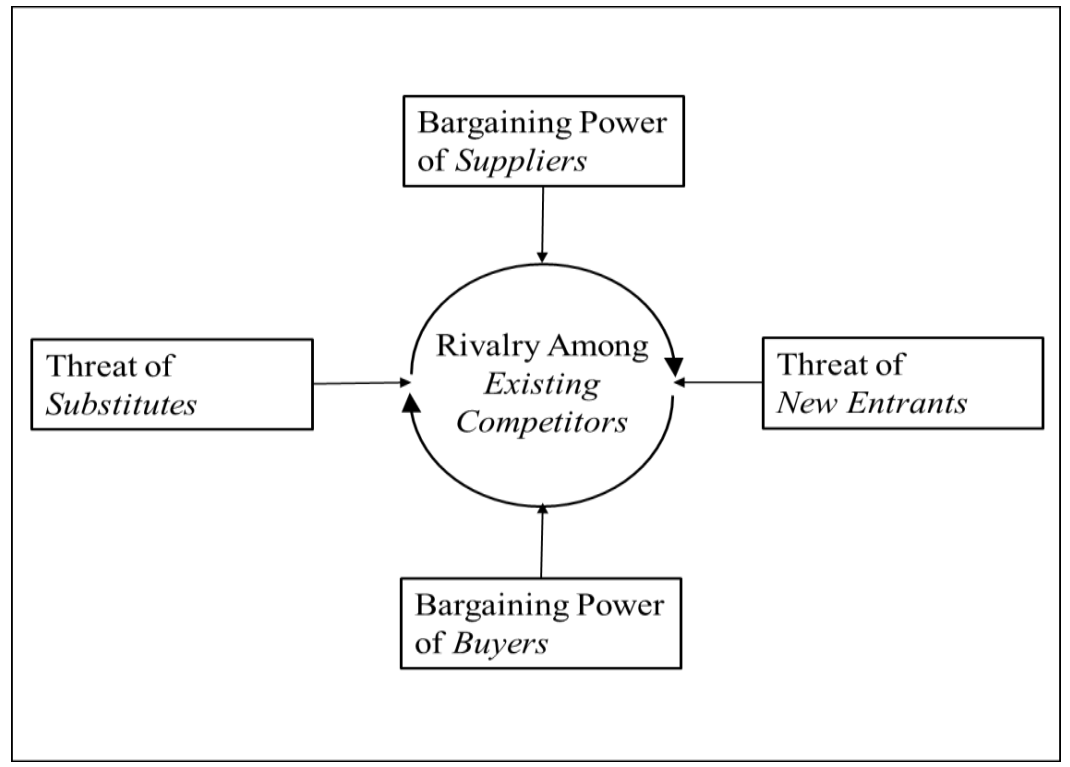

Source: Porter (2008). 
The RBV can be utilized to identify which resources and capabilities a firm should possess in a particular country's specific sector to gain sustainable competitive advantage and thus be successful in a certain country's business sector. Based on this outcome, the best fitting entry mode strategy for a specific market can be determined. Meyer et al. (2009) found that when MNEs are highly dependent on resources and capabilities that are context-specific, firms rather enter through an acquisition or joint venture (JV), as these gain access to foreign resources and capabilities, compared to a greenfield. Due to certain restrictions that are context-dependent a firm tends to choose one of the collaborative entry modes - JV or acquisition - above the other.

\subsubsection{Decision-making process and application of the framework}

After the execution of the abovementioned three analyses a firm faces two decisions. Firstly, how to acquire missing resources and secondly, an investment decision (entry mode). According to Laserre (2007), entry mode can be based on type of ownership and the intensity of an investment (see figure 5). Decision-making is furthermore affected by the expected outcomes of a specific decision.

Porter's national diamond and five forces framework provide comprehensive sector-level industrial information. The industrial analysis gives the input for relevant resources and capabilities analysis. The RBV is applied by focussing on the critical resources and capabilities that are required to succeed in a particular business sector within a particular EM. This in turn leads to the decision-making process. The entry mode depends on both the contextspecificity of required resources and capabilities, the firm's internal set of resources and capabilities and the expected performance. This analysis is directly affected by the institutional context that is analysed through Whitley's Business Systems Theory and Hall \& Soskice's Varieties of Capitalism. 
Figure 5. Entry mode choice based on intensity of investment and ownership dimension

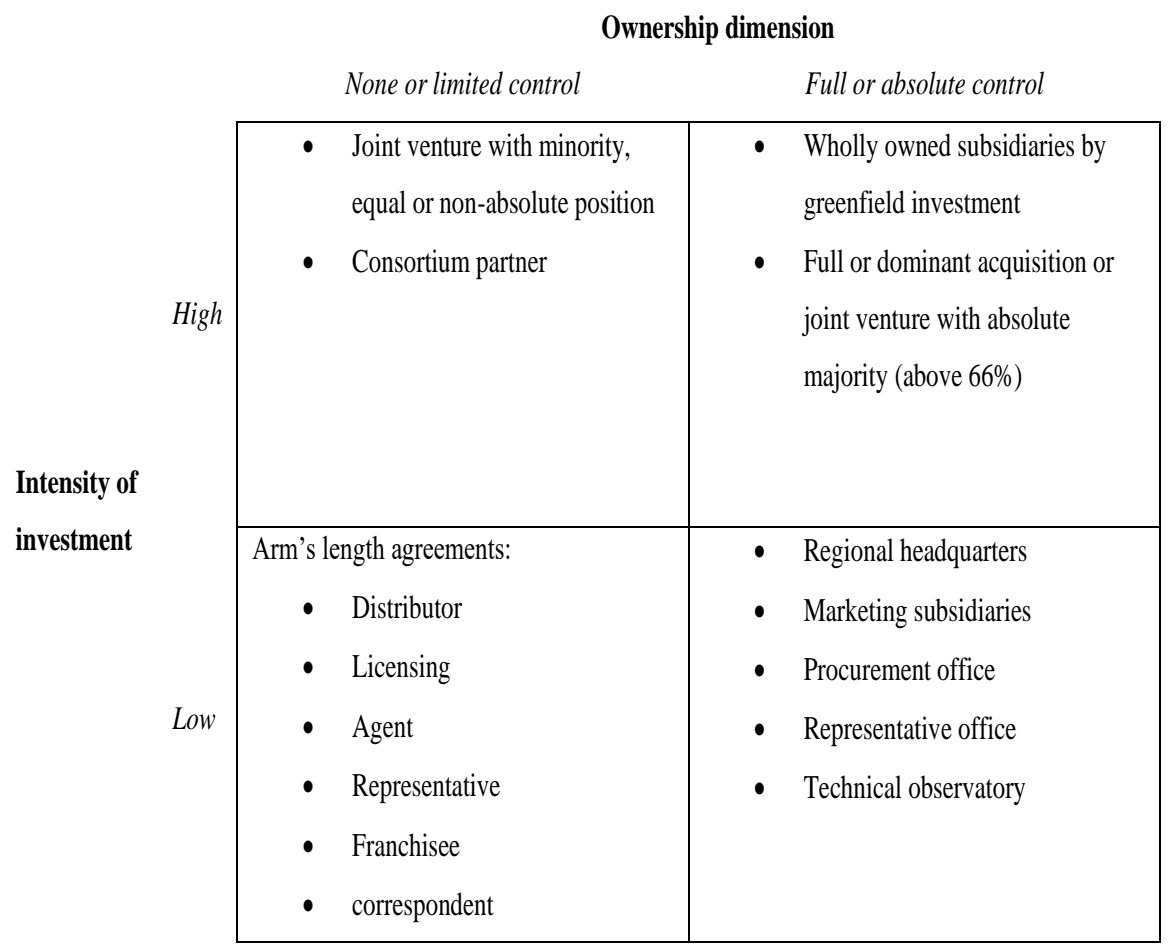

Source: Laserre (2007).

\subsection{The Bottom-of-the-Pyramid}

\subsubsection{The emergence of the notion of the BoP}

Despite large amounts of money that were spent on aid-based programs by governments, charities and NGOs have not proven to have long-lasting effects on poverty alleviation and livelihood improvement of the poorest people in society. Prahalad and Hart (2002) therefore suggested that there lies a great possibility for wealthy multinationals for growth and opportunity while they simultaneously fight poverty (Dembek et al. 2020). This hybrid motivation of social value generation while gaining economic profits has become the basis of the ideas behind the BoP (Borchardt et al. 2020). 
Prahalad (2006) found that in the past the lowest-income groups worldwide were often left out of the process of globalization. He argues that this market should be given attention as potential expansion targets for MNEs, especially those from the developed world (Hillemann, Verbeke 2014). The idea of a potentially profitable market at the $\mathrm{BoP}$ is especially appealing due to its size: with approximately four billion it represents more than half the population worldwide (Dembek et al. 2020; Borchardt et al. 2020). The aggregated purchasing power of more than US $\$ 5$ trillion of the potential consumers in the $\mathrm{BoP}$ is regarded as an enormous untapped market that offers MNEs a great path for future growth and innovation (Zhu et al. 2019; Hillemann, Verbeke 2014; Primus et al. 2017). Furthermore, the rising income of the potential BoP consumer and low competitive intensity have been used to emphasise the attractiveness of BoP-markets (Primus et al. 2017).

\subsubsection{The BoP-market}

Poor communities are located in over a hundred countries worldwide, both developing countries and EM economies such as Brazil, Russia, India and China (Borchardt et al. 2020). While more recent published works have been critical on income level as a criterion for poverty (e.g. Kolk et al. 2014; Subhan, Khattak 2017), most researchers consider low income as a key characteristic of BoP communities. Prahalad and Hart (2002) determined that communities with a daily income of maximum US\$2 per capita would compose the BoP. However, other researchers used other benchmarks such as US $\$ 4.50$ and US\$8. Depending on the measure that is being used, BoP-markets consist of between 2.7 and five billion individual people worldwide (Landrum 2014; London, Hart 2010; Chmielewski et al. 2020; Subhan, Khattak 2017).

\subsubsection{General characteristics of the BoP}

While there is no clear consensus on the demographic aspects of the BoP, scientific literature often does identify the same three generic characteristics that are present in every BoP-market. Firstly, organizations have hybrid motivations, i.e. economic profitability, social impact and sometimes also 
environmental impact (Chiliova, Ringov 2017). Secondly, resource scarcity, both in terms of BoP consumers' income and resources that are needed to provide for basic needs such as food, safe drinking water, shelter, energy, sanitation, and health (Borchardt et al. 2020; Lappeman et al. 2018). Thirdly, weak or absent institutional context, where informal institutions and economic activity prevail, formal regulation lacks or is not enforced, corruption is omnipresent and market-supporting institutions such as property rights protection are missing (Borchardt et al. 2020; Lappeman et al. 2018).

\subsubsection{Constraints in the BoP for MNEs}

Success in the BoP comes far from easy for developed-country MNEs. The main constraints are firstly the income of the BoP community, which brings a significant challenge to MNEs in terms of cost management and product or service design. Furthermore, BoP communities are often characterized as having low awareness, e.g. on healthy nutrition, and a lack of access to financial resources (Primus et al. 2017). Additionally, due to the often geographically dispersed residential areas of the $\mathrm{BoP}$ community and infrastructure to reach them is lacking or very low in quality, MNEs have to come up with innovative solutions to distribute their products or services to them (Tasavori et al. 2014).

\section{Differences between BoP and non-BoP thinking: coming up with sensitizing concepts}

This chapter describes the differences between traditional EM internationalization strategies and specific BoP-strategies. Additionally, it presents on which factors MNE success depends when entering a BoP-market according to current literature. Finally, by combining this knowledge and the literature review of the previous chapter, the main key questions are formulated for this research. These questions are like sensitizing concepts, used to guide observations, that give direction for research on how to make the existing frameworks more applicable in the context of the BoP. It is an initial thinking model that is further developed when 
studying the results that become apparent after the qualitative research (Jonker, Pennink 2010).

\subsection{Key differences between $B o P$ and non-BoP strategies}

BoP strategies differ significantly from non-BoP internationalization strategies towards EMs when it comes to their goal, target market, business models, products and service design and cost structures (Landrum 2014).

\subsubsection{Goal}

Conventional FDI strategies towards EMs often have one goal, which is to increase profitability. Improving the social or environmental circumstances is regarded as philanthropy. BoP strategies on the other hand are based on creating mutual benefits by alleviating poverty of the local community and improving social sustainable development, while still being profitable as a corporation (Hillemann, Verbeke 2014). Prahalad and Hart (2002) initially presented the $\mathrm{BoP}$ as mere consumers to which goods and services from developed economies are being sold, and was regarded as a profitable market due to the vast amount of people it entailed. The goods and services are adjusted inter-firm (top-down) to the BoP communities to suit these markets, for example by product downscaling to meet a certain price point. This view has become known as BoP 1.0. However, since the initial criticisms by e.g. Karani (2007), ethical and environmental concerns in the context of the $\mathrm{BoP}$ are rising. Focus had to be on empowering BoP communities and engaging with them to alleviate poverty and improve their lives, instead of merely selling to them. With this BoP 2.0 thinking, these communities are regarded as local entrepreneurs distributors and suppliers - that are engaged in the process of the bottom-up creation of products and services specifically for this market (Dembek et al. 2020; Chmielewski et al. 2018; Dionisio 2016).

One of the main conditions for a BoP strategy is the hybrid motivation of an $M N E$. However, the existing frameworks generally do not take into account another bottom line than making profit. This gives rise to the following question: 
1. How can hybrid motivations of MNEs - generating social value while gaining economic profits - be incorporated in a framework?

\subsubsection{Target market, business models and design of products and services}

Many MNEs focus solely on the ToP, while the BoP often excluded. These firms follow a non-BoP FDI strategy in which they adapt their traditional business model to the local market. MNEs with a BoP strategy include the BoP community directly. The design for the product and services they deliver is organized from the bottom-up, together with the BoP community, instead of inter-firm top-down, like many non-BoP strategies (Landrum 2014). Due to their low income and a lack of complementary infrastructures, goods and services in the regions they live in, products made and developed in developed countries would not suit BoP-market consumers. Therefore, MNEs are required to adapt to these environments by finding innovative ways to cope with several contextual factors, including the consumers' low income and their particular needs and wishes (Hillemann, Verbeke 2014). According to Prahalad and Hart (2002: 2) these products and services should be "culturally sensitive, environmentally sustainable and economically profitable." BoP strategies consider BoP communities not only as consumers to which they merely sell their goods and services, but often involve them as producers or partners for knowledge sharing to fit the product, distribution and supply with the needs and wishes of the BoP community (Kolk et al. 2014). Finally, BoP strategies tend to create new cost structures to make products affordable for BoP consumers, where non-BoP strategies for EMs merely have to refine and minimize cost structures in order to be affordable for the ToP markets they serve (Landrum 2014).

MNEs have to cope with contextual factors that are specific for BoPmarkets and make significant changes in the design and cost structures of their products and services based on these characteristics. It is argued that this is at the basis of MNEs strategy in the BoP (Chliova, Ringov 2017). Some of these 
characters are the same for every BoP market, others will be contextdependent. Therefore, the following question arises:

2. Which general and context-specific characteristics are considered to be important for MNEs with activities in the BoP and how can they be included in a framework?

\subsection{MNE success in the context of the BoP}

MNEs from developed countries have an institutional distance with the BoP in terms of product, capital and labour markets, regulatory systems and systems for contract enforcement. They lack local market contacts and knowledge (Van den Waeyenberg, Hens 2012). Therefore, MNEs should have social embeddedness in which they understand the BoP-markets and how the local community works by having a two-way interaction between the community and the MNE (Hart 2010). Scholars suggest that MNEs should collaborate with non-traditional local partners to gain local knowledge and credibility, for example with NGOs and local governmental organizations (London, Hart 2004; Hart 2010; Van den Waeyenberg, Hens 2012). This way, MNEs gain an understanding of what the communities need, and what their strengths and vulnerabilities are. This bottom-up approach help MNEs learn about the markets and sees the circumstances in the BoP as heterogeneous (Pels, Sheth 2017).

Previous frameworks present a limited amount of entry modes in their frameworks. As the context of the BoP poses many challenges and MNEs have hybrid motivations, other entry modes might exist that are a better fit with the BoP. Therefore, the following question arises:

3. Does the collection of entry modes that previous researchers describe in their models fit with the context of the BoP, or can other entry modes be included as well?

While weak institutions and institutional voids are often seen as a general characteristic for the BoP, Ault and Spicer (2008) argue that next to the institutional differences between the layers in the economic pyramid, significant 
institutional differences also exist between different countries with substantial BoP populations. Therefore, labelling BoP institutions as universally weak is too short-sighted (Kistruck et al. 2015). Ault and Spicer (2008) argue that a careful analysis of the institutional context in the BoP is necessary before the potential success of the MNE's activities in the BoP can be evaluated. Furthermore, political stability is often lacking in the BoP. This affects the informal economic relations in the sense that extortion, bribery and corruption are more common to occur (Ault, Spicer 2008).

As Witt and Redding (2013) found in their analysis of different business system theories including the theories of Whitley (1999) and Hall and Soskice (2003), none of the models incorporates institutional informality. Stable formal institutions, such as a stable financial system and rule of law are taken for granted in these models (Leszczyński 2015). Additionally, Zhu et al. (2019) argue that both the industry-based view and the RBV ignore the fact that formal institutions can be weak and under-developed, and that informal institutions prevail. Therefore, the following question arises:

4. How can the general and context-specific characteristics of the BoP institutional context be analysed in the framework?

Linked with the institutional context of the BoP is the transferability of the resources and capabilities from the MNE's developed home market towards the context of BoP-markets. Due to institutional voids MNEs might not be able to depend on the resources and capabilities they collected and developed in their home country. Therefore, Van den Waeyenberg and Hens (2012) argue that only those capabilities that are independent of the institutional context managerial, financial, technological and learning ability (Hart 2010) - can be transferred to an MNE's operations in the BoP.

The $R B V$ is merely applicable if the institutional context of a country is relatively stable. When institutional environments are unpredictable, as is the case in BoP-markets where rules and regulations are fluctuating and enforcement is not 
certain, a firm's sustainable comparative advantage is more complex (Kraaijenbrink et al. 2010). Thus, the following question arises:

5. Which resources and capabilities are needed to gain competitive advantage in the context of the BoP?

\section{Methodology}

\subsection{Research design}

This research utilizes a qualitative, multiple-case study research design to answer the open research question. It is exploratory research in which multiple cases are compared with each other, which could be classified as a combination of deductive and inductive theory building and hypotheses generation (Birkinshaw et al. 2011). Since the context of the BoP is highly complex and the behaviour of MNEs in these contexts can make the BoP especially complicated, a qualitative approach was regarded as most suitable to meet the objective of the study (Creswell, Creswell 2018). An advantage of a multiplecase study approach is that it reduces the researcher's biases and it increases the opportunity to create empirically valid theories (Eisenhardt 1989). Furthermore, complex causal links can be analysed and explained by a variety of factors (Yin 2018), which is highly convenient for studying BoP-markets, as these are significantly different from ToP-markets. Additionally, a multiple case-study can be applied to either predict similar results or contrasting results for a predictable reason (Yin 2003). This is also critical to the context of the BoP as the understanding of this context is not yet sufficiently advanced in the existing literature and much uncertainty in explaining MNE-decisions in the context of the BoP - such as market entry - still exists (Schuster, Holtbrügge 2012).

\subsection{Research sample}

This study examines how MNEs take into account the specific contextual and generic factors of the BoP-market. Therefore, the sample exists out of 
managers at MNEs that are directly involved in the MNE's activities in the BoP. The interviewees were identified through networking. Experts on the BoP and managers at MNEs with activities in the BoP were within the authors' network were contacted at first. These respondents in turn offered their network for contacting other experts and MNEs that operate in BoP-markets. Thus, a snowball sampling strategy was applied to identify the relevant interviewees and connect with them (Bryman, Bell 2015). This eventually resulted in a sample of ten respondents from ten different organizations. The sample includes two experts from non-profit organizations specialized in the BoP and eight managers from eight different MNEs with activities in the BoP.

\subsection{Data collection and method of analysis}

Primary data is collected by conducting ten semi-structured interviews. This interviewing technique allows the interviewer to collect the data in a flexible yet organized matter. All interviews were conducted in the months November and December 2020. During the interviews emerging countries with BoP-markets within Asia and Africa were addressed, including India, Ethiopia, Kenya, Bangladesh, Nigeria and Myanmar.

Due to practical matters all interviews were conducted online in either a call or a video conversation instead of in person. Based on the outcomes of the first interview with the first expert, the interview guide for MNEs was slightly adjusted for the interviews with the MNE managers. The interview questions are structured in a thoughtful and strategically planned order. However, this did not mean that there was a final interview script beforehand, as is the case in structured interviews. The setting of the interviews is that of an interactive conversation in which more in-depth (follow-up) questions can be asked (Adams 2015). To analyse the data that was being collected later on, the researcher recorded the interviews after asking the interviewees for permission. In order to discover and generate theory based on the data collection "that is grounded in practice" (Jonker, Pennink 2010: 84) this research applies the grounded theory approach. The internal publication (Broeksma 2021) goes more in depth on the data analysis of this research. 
The interviewees gave well-founded and extensive answers to the open questions they were asked. These answers allowed the researchers to formulate an answer on how to involve the BoP in a strategy for entering emerging markets. For more insights into the data that was collected the authors can be contacted at the email address that is stated in the correspondence address. ${ }^{1}$

\subsection{Validity, reliability and transparency}

This study strives to meet construct validity through using a clear chain of evidence by showing how the findings in the case study were reached through the data collected and in turn from the initial research question and the casestudy protocol (Yin 2018; Gibbert et al. 2008). The fact that the first three transcripts are coded line-by-line and therefore decreasing the chance of making biased assumptions also increases the construct validity of this study. External validity is increased as this study utilizes a cross-case analysis through doing eight case studies at eight different organizations (Gibbert et al. 2008). Reliability is increased by leading the interview as little as possible. Furthermore, the researcher attempts to reduce interviewer bias by maintaining a professional attitude towards the interviewees from the first contact on. Furthermore, reliability is increased through carefully pursuing the research design. To enhance transparency, the case study database in which all interview transcripts are included is made available to the University of Groningen and can be provided on request. Additionally, the research utilizes a sensitizing approach in which the thoughts of the researcher throughout the study can be followed.

\section{Results and discussion}

The interviews enabled the researcher to answer the five sensitising questions that were presented in paragraph 3 . This paragraph aims to explain how the initial

\footnotetext{
${ }^{1}$ b.j.w.pennink@rug.nl
} 
framework for analysing business sectors in EMs can be extended by adding the findings from the interviews.

\subsection{How the institutional context of the $\mathrm{BoP}$ can be integrated into a framework}

Formal institutions are lacking in the BoP-market, such as quality control, formal regulations and their enforcement, property rights and corruption. Therefore, managers should analyse the different institutional voids (figure 6, IE) when developing their BoP-strategy as every void has a unique effect on the organization. MNEs might want to overcome institutional voids by working together with a variety of partners (private, public, non-profit) (Parmigiani, Rivera-Santos 2015). The results strengthen the findings of Zhu et al. (2019) that corruption results in unfair actions from competitors. They suggest that managers should closely observe the weak institutional environment in the BoP to adapt their strategy for this market. Government involvement in the activities of the MNE in the BoP (figure 6, IE), especially knowing a government's agenda for the BoP and their views on topics such as healthy nutrition play an important role for MNEs. Firms can gain more market opportunities when a government is supportive, e.g. in terms of social marketing and behavioural change programs and subsidies (Zhu et al. 2019). Furthermore, MNEs should actively analyse the varying cultural traits, i.e. the informal institutions, and incorporate these findings into their strategy. These findings are substantiated by those of Kuo et al. (2016), who found that firms have to understand the various BoP demands, based on their cultural traits, to develop a fitting strategy for the BoP.

\subsection{How the hybrid motivations of the MNE fit in a framework}

It became clear that their main focus, next to profit, was to create a situation in which the local BoP community has a socio-economic gain in the long term. MNEs often work together with partners in these training- and empowerment programs. This goal seems to fit into the definition of Lashitew et al. (2021: 3) of social value creation (figure 6, EP): "business-led approaches for improving the socio-economic well-being of BoP communities in an economically viable 
manner." MNEs work with vulnerable communities with many disadvantages in their lives. Therefore, doing business in the BoP requires "an organizational culture of deep reflection and care" (Lashitew et al. 2021: 14) to prevent undesired socio-economic outcomes that are the result of MNE interventions. In order to gain local ethical sensitivity it can be even more important to have a deep understanding of the BoP. Partnerships can be useful for this.

\subsection{How specific BoP characteristics can be incorporated in a framework}

One of the main factors in the BoP that MNEs have to take into account is a deep understanding of the general and local context-dependent BoP characteristics. The main factors to take into account are explained below and can be found in figure 6 under 'BoP orientation'.

Accessibility and last-mile distribution to the $\mathrm{BoP}$ is seen as one of the most difficult aspects and is often underestimated by MNEs. Therefore, understanding where the BoP consumers buy and meet each other is important, as often informal channels are used. The results confirm previous findings by Campos (2020) that MNEs tend to innovate their business models by designing new distribution models, e.g. recruiting and training women as sales personnel for door-to-door sales models to access BoP consumers. Furthermore, the results of this study reinforce the importance of understanding and adapting to the specific needs of the BoP consumer, and therefore the importance of understanding the context-dependent habits and behaviours that form the specific needs of the consumer as was found by Anderson and Billou (2007). This research extends the research of Anderson and Billou (2007) by highlighting the consumers wants instead of their needs. Wants might even play a bigger role in the BoP, and the BoP consumer's aspirations have to be understood as well. These findings are also highlighted by Gupta and Srivastav (2016), who urge firms that target the BoP to understand BoP consumers' aspirational needs, adjust their business models to this and develop affordable products and services that fulfil these aspirations. MNEs are often involved in behavioural change and social marketing programs to make the product aspirational, create demand and educate the users on the product. It became 
evident that knowledge, information and education are often lacking in the BoP causing its consumers to not understand the added value of a product, for example in the case of fortified nutritious products. Local partners can support the MNE with social marketing. Van den Waegenberg and Hens (2012) found that non-governmental organizations often support MNEs in social marketing because of the credibility they have in local BoP communities. Furthermore, in line with the findings of Chikweche and Fletcher (2012), the low income and limited buying power of the BoP consumers, their affordability, are factors that play a large role in the product design and innovation and the business operations in the BoP. Saving or borrowing money to make larger investments is often not possible because of lacking access to finance. To reduce costs and enhance the consumer's capacity to buy the product, local resources and raw materials are often used. Furthermore, downscaling in terms of size and cheaper ingredient substitutes are often used to reduce costs. Additionally, partnerships with other MNEs are sought to share distribution networks. Also, BoP consumers often are very value and quality conscious. Therefore, the MNE has to find the right balance between offering a low-cost product that has a high level of quality and value (Pitta et al. 2008). Chikweche and Fletcher (2012) underline the macroenvironmental constraints for pricing strategies in the BoP that have to be taken into account, such as currency risks, as was found during this study.

The results of this study confirm the findings of Hillemann and Verbeke (2014: 86), who argue that "MNEs should consider the "normal" economic, political and other environmental parameters [...], instead of focusing exclusively on their ability to innovate to create new goods for BoP consumers." Therefore, existent frameworks can be advanced with a "BoPanalysis" in which the contextual factors of the BoP are analyzed and MNEs acquire a deep understanding of the local context. This BoP-analysis exists on the one hand of characteristics that are generic for every BoP-market worldwide: low buying power, limited access to finance, need for high-quality products and lacking education, information and knowledge in the BoP. On the other hand, consumer characteristics also can be context-dependent and differ 
significantly per BoP community: habits, behaviours, needs and wants, buying channels, accessibility both in terms of infrastructure and geography and their definition of an aspirational product. Zhu et al. (2019) offer a tool for this as they propose a new construct called 'BoP orientation', the "capability to serve the needs of BoP consumers based on a thorough understanding of their unique characteristics" (Zhu et al. 2019: 4). Added to this research is the distinction between context-dependent and general characteristics, the context-specific wants and aspirations of BoP consumers, and the general need for high-quality products of BoP consumers.

\subsection{Which resources and capabilities are needed for the BoP}

The capability of having a thorough understanding of the BoP community and its characteristics before entering this market is seen as vital for the success of the BoP. Many interviewees mentioned creating partnerships with various local non-market parties to gain local knowledge, such as universities, NGOs and governments. Furthermore, it was mentioned that the MNE works together with the local people in the BoP to create a product and thus utilize a bottom-up approach. These findings are substantiated by Sánchez and Schmid (2013) as they argue that partners can create a competitive advantage for the MNE when firms are missing the knowledge to develop a BoP-orientation. Partners can assist in the co-development of products, distribution channels and educations programs by sharing their knowledge on the local BoP-market. Sánchez and Schmid (2013) call this the relational view (figure 6, RC) of strategy, which builds on the RBV by adding that competitiveness is a result of combining resources and knowledge of multiple partners instead that together form relational capabilities. The relational view is included in the framework as addition to the RBV.

\subsection{How MNE entry mode in the BoP fits in a framework}

Public Private Partnerships (PPPs) (figure 6, EnM) appeared as a mode to enter the BoP. These alternative business models are argued to be especially useful in developing and transitioning economies (Vinogradov et al. 2009). 
PPPs are collaborations between governments and private firms, in which the government acts as a buyer for the BoP community, which are beneficial for both parties (Primus et al. 2017). While no clear consensus was found on a strategic choice for entry mode, partnerships (figure 6, EnM) turn out play a vital role for MNEs in the BoP-market. Therefore, the framework can also be utilized to make a strategic choice for a partnership. Partnerships can be used to both gain local knowledge and get an understanding of the BoP, to deal with governments and regulations and to support training and support programs for the local community, including the education and training of farmers.

\subsection{Framework developments when including the context of the BoP}

This framework fills the gap presented in the introduction as it includes the $\mathrm{BoP}$ and additionally makes it possible to detect differences in BoP-markets between countries. The suggested BoP-orientation analysis is recognizable by the darker markings. All further additions to the initial frameworks are in italics. Due to the sensitizing character of this research, this extended framework should not be regarded as a final concept, but rather as a general idea of a framework that can help to steer future research in a certain direction. Some outcomes of the framework might overlap with outcomes from other analyses, for example the institutional environment and Porter's Diamond on the government's role. Due to the many mutual relationships that were found, different starting points in the model are encouraged. Based on the grey arrows that show the relationships between the analyses, starting with the institutional environment analysis and following up with the BoP orientation might make sense, since these both influence many other analyses. 
Figure 6. How to come to good decisions on entry strategies integrating local and general factors from the $\mathrm{BoP}$

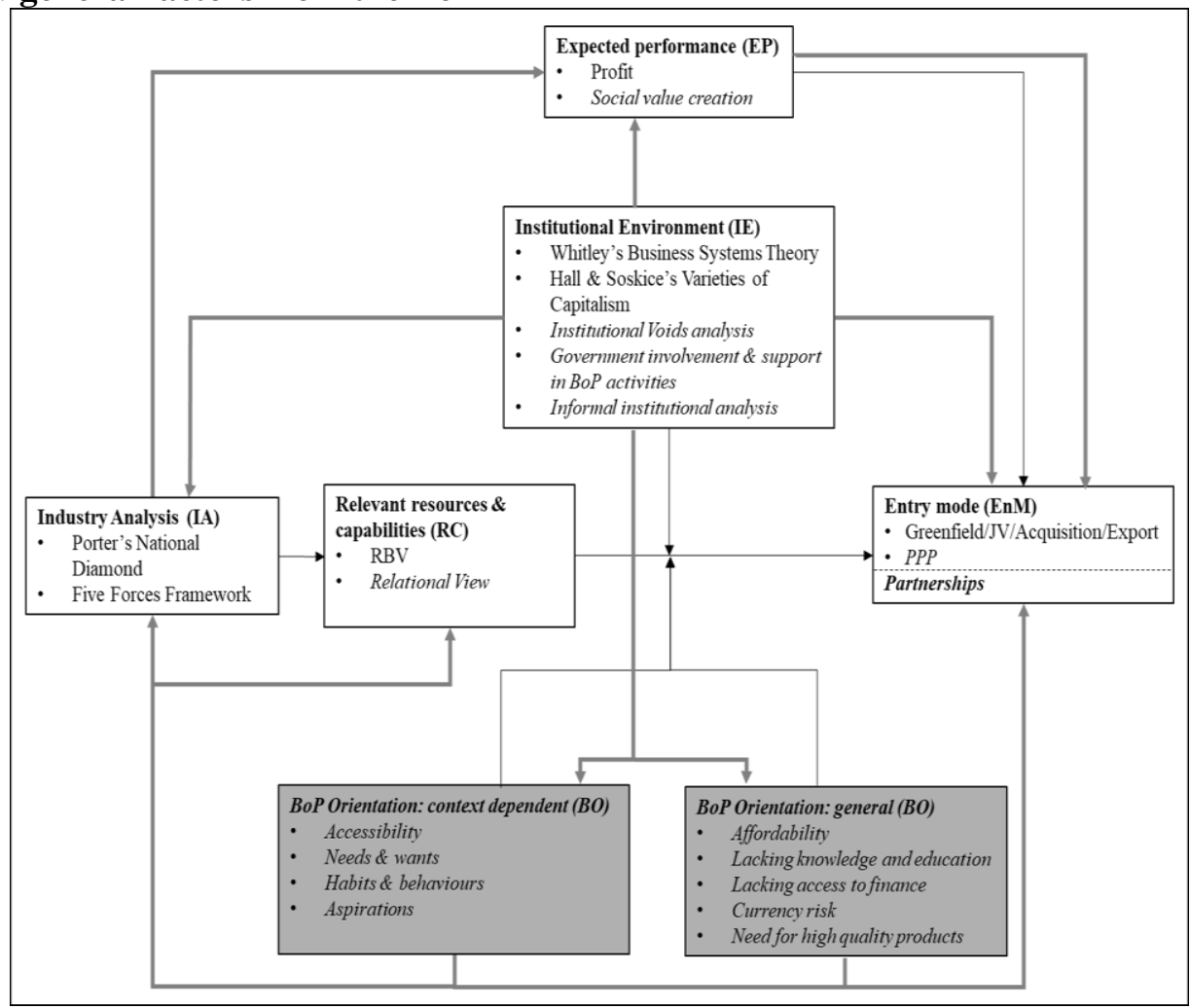

\section{Conclusion}

The main objective of this study was to find an answer on the following open research question: 'How does a framework for analysing business sectors in emerging markets look like when taking into account the local contextdependent and general factors of the BoP?'. At first, a sensitizing concept has been created in the form of five questions on the applicability of existing frameworks for analysing EM business sectors on the segment of the BoP. These questions are based on combining the knowledge of those frameworks with existing literature on the BoP. As many current models for the BoP are based on one-size-fits-all principles, and current frameworks for analysing EMs 
that do take into account different contexts and situations fall short to be applicable to the BoP, this research makes both a theoretical and managerial contribution to the current literature. Firstly, it fills a theoretical gap in which the context-specific factors of the $\mathrm{BoP}$ are being considered by presenting a framework for analysing BoP-markets. Secondly, this research fills a managerial gap by enabling MNEs with a framework for making strategic decisions when entering the BoP. By interviewing experts on the BoP and managers at MNEs with activities in the BoP, it has been possible to collect empirical evidence and increase the understanding of how BoP-markets are analysed and eventually entered by MNEs. Through an analysis of the interviews, the sensitising concept has evolved into an advanced framework for analysing EM business sectors that is also applicable to the BoP-market. Additionally, due to the illustration of numerous links between analyses that were found, the framework can be understood better.

This research has filled the theoretical gap by designing an advanced framework through which the BoP can be analysed, and also differences between BoP-markets can be found. As was expected, a one-on-one copy-paste of a BoP strategy between different BoP-markets is not possible because of significant differences between BoP-markets and their communities. The involvement of the government in the activities of the MNE and their agenda on the BoP is different in every market, which affects the opportunities in the market. Furthermore, it was found that formal institutions are weak and institutional voids are omnipresent. Therefore, next to an analysis of the institutional voids in a market, an informal institutional analysis has been added to the framework in which the national cultural traits that influence the operations of the MNE are analysed. It became evident that MNEs have an outside-in motivation of social value creation that can influence strategic choices (entry mode and partnerships selection) which requires a deep understanding of the $\mathrm{BoP}$ and their needs by having a $\mathrm{BoP}$ orientation. Therefore, the BoP orientation box has been added to the framework in which both general and context-specific characteristics that MNEs have to take into account in the BoP are included. The finding of the importance of 
understanding the wants and aspirations of the $\mathrm{BoP}$ was somewhat surprising as many previous studies do not seem to focus on this specific characteristic. This deep understanding of the BoP turned out to be the main source for MNEs to acquire competitive advantage, which is often gained through partnerships with local non-market parties. Therefore, this research argues that competitiveness in the $\mathrm{BoP}$ is reached through relational capabilities. Partnerships turned out to play a vital role, as they not only support the MNE in understanding the BoP but also help in dealing with local institutions and are used to reach the social goals of the MNE by supporting it in training and support programs for the BoP community. Finally, the option of PPPs as entry mode has been added to the model.

\section{Limitations and future research}

This research has multiple limitations and thus presents several suggestions for future research. First and foremost, the generalizability of the findings has to be handled with caution beyond this study as the applicability of this framework in the BoP has not been tested yet. Therefore, this advanced framework should be tested for its adequateness in analysing a business sector in a BoP-market. Further studies can research whether Hofstede's theory of cultural dimensions and the relational based view can be useful additions to the framework. Furthermore, future research is urged to research how MNEs choose their entry mode in the $\mathrm{BoP}$ as no generable answer in this research was found. Additionally, the research sample consists of exclusively Dutch interviewees. Managers' national culture might have a strong influence on managerial behaviour (Pizam et al. 1997). Therefore, a study with merely Dutch managers might not be suitable to make general conclusions on this study's external validity. This is why further studies might want to repeat this study using a sample of managers with a variety of nationalities. Furthermore, due to the rather limited amount of MNEs that have known activities in the BoP and were open for an interview, the researcher was not able to distinguish between B2B and $\mathrm{B} 2 \mathrm{C}$ markets, and neither managed to create a sample that includes a variety of industries. Future researchers are urged to test whether the framework 


\title{
Maaike Maren BROEKSMA, Bart Jan Willem (Bartjan) PENNINK
}

\author{
is applicable in both the case of B2B and B2C MNEs, as well as its applicability \\ in a variety of industries.
}

\section{References}

Adams W.C. (2015), Conducting semi-structured interviews, in: Handbook of practical program evaluation, Newcomer K.E., Hatry H.P., Wholey J.S. (eds.), Josey-Bass, San Francisco, pp. 492-505.

Anderson J., Billou N. (2007), Serving the world's poor. Innovation at the base of the economic pyramid, "Journal of Business Strategy", vol. 28 no. 2, pp. 14-21.

Ault J.K., Spicer A. (2008), Comparative institutional advantages at the bottom of the pyramid: explaining cross-national differences in the growth of commercial microfinance, Working Paper, University of South Carolina, Columbia, https://citeseerx.ist.psu.edu/viewdoc/download?doi=10.1.1.500.5606\&rep=rep1\&type=pdf [10.06.2021].

Barney J. (1991), Firm resources and sustained competitive advantage, “Journal of Management”, vol. 17 no. 1 , pp. $99-120$.

Becerra M. (2009), Theory of the firm for strategic management: economic value analysis, Cambridge University Press, Cambridge.

Birkinshaw J., Brannen M.Y., Tung R.L. (2011), From a distance and generalizable to up close and grounded. Reclaiming a place for qualitative methods in international business research, "Journal of International Business Studies”, vol. 42, pp. 573581.

Borchardt M., Ndubisi N.O., Jabbour C.J.C., Grebinevych O., Pereira G.M. (2020), The evolution of base of the pyramid approaches and the role of multinational and domestic business ventures: valuecommitment and profit-making perspectives, "Industrial Marketing Management", vol. 89, pp. 171180.

Broeksma M.M. (2021), Taking the Bottom-of-the-Pyramid (BoP) and the local context serious. Integrating general and local context-dependent factors from the bop into a framework for analysing business sectors in emerging markets, internal publication, University of Groningen Faculty of Economics and Business, Master Thesis University of Groningen.

Bryman A., Bell E. (2015), Business research methods, 4th ed., Oxford University Press, Oxford.

Campos H. (2020), Innovation revolution in agriculture. A roadmap to value creation Springer In Press, Switzerland.

Chikweche T., Fletcher R. (2012), Revisiting the marketing mix at the bottom of pyramid (BOP). From theoretical considerations to practical realities, "Journal of Consumer Marketing", vol. 29, no. 7, pp. 507-520.

Chliova M., Ringov D. (2017), Scaling impact. Template development and replication at the base of the pyramid, „Academy of Management Perspectives”, vol. 31, no. 1, pp. 44-62. 


\section{INTEGRATING GENERAL AND LOCAL CONTEXT-DEPENDENT FACTORS ...}

Chmielewski D.A., Dembek K., Beckett J.R. (2020), 'Business unusual'. Building BoP 3.0, “Journal of Business Ethics", vol. 161 no. 1, pp. 211-229.

Creswell J.W. (2014), Research design. Qualitative, quantitative, and mixed method approaches, 4th ed., Sage Publications, Thousand Oaks.

Creswell J.W., Creswell J. D. (2018), Research design. Qualitative, quantitative \& mixed methods approaches, 5th ed. (International student edition), Sage Publications, Thousand Oaks.

Cui L., Jiang F. (2012), State ownership effect on firms' FDI ownership decisions under institutional pressure. A study of Chinese outward-investing firms, "Journal of International Business Studies", vol. 43 no. 3, pp. 264-284.

Dembek K., Sivasubramaniam N., Chmielewski D.A. (2020), A systematic review of the bottom/base of the pyramid literature. Cumulative evidence and future directions, "Journal of Business Ethics", vol. 165 no. 3 , pp. 365-382.

Dionisio M.A. (2016), Evolution of the Base of the Pyramid (BOP) construct through a bi-dimensional perspective, "European Journal of Business and Social Sciences", vol. 5 no. 7, pp. 38-50.

Eisenhardt K.M. (1989), Building theories from case study research, "Academy of Management Review", vol. 14 no. 4, pp. 532-550.

Estrin S., Prevezer M. (2011), The role of informal institutions in corporate governance: Brazil, Russia, India, and China compared, “Asia Pacific Journal of Management”, vol. 28 no. 1, pp. 41-67.

Gibbert M., Ruigrok W., Wicki B. (2008), What passes as a rigorous case study?, "Strategic Management Journal”, vol. 29 no. 13, pp. 1465-1474.

Gupta S., Srivastav P. (2016), An exploratory investigation of aspirational consumption at the bottom of the pyramid, "Journal of International Consumer Marketing", vol. 28 no. 1, pp. 2-15.

Hall P., Soskice D. (2001), An introduction to varieties of capitalism, in: Varieties of capitalism. The institutional foundations of comparative advantage, Hall P., Soskice D. (eds.), Oxford University Press, Oxford, pp. 1-70.

Hart S.L. (2010), Capitalism at the crossroads. Next generation business strategies for a post-crisis world, Wharton School Publishing, New Jersey.

Hillemann J., Verbeke A. (2014), An internalization theory perspective on the Bottom of the Pyramid, "Progress in International Business Research", vol. 8, pp. 69-90.

Hotho J.J. (2014), From typology to taxonomy. A configurational analysis of national business systems and their explanatory power, "Organization Studies", vol. 35 no. 5, pp. 671-702.

Jamali D., Karam C. (2016), Corporate social responsibility in developing countries as an emerging field of study, "International Journal of Management Reviews", vol. 20 no. 1, pp. 32-61.

Jonker J., Pennink B. (2010), The essence of research methodology. A concise guide for master and $\mathrm{PhD}$ students in management science, Spinger, Berlin, Heidelberg. 


\section{Maaike Maren BROEKSMA, Bart Jan Willem (Bartjan) PENNINK}

Kistruck G.M., Webb J.W., Sutter C.J., Bailey A.V. (2015), The double-edged sword of legitimacy in base-of-thepyramid markets, "Journal of Business Venturing", vol. 30 no. 3, pp. 436-451.

Kolk A., Rivera-Santos M., Rufin C. (2014), Reviewing a decade of research on the "Base/Bottom of the Pyramid" (BOP) concept, "Business \& Society", vol. 53 no. 3, pp. 338-377.

Kraaijenbrink J., Spender J.C., Groen A.J. (2010), The resource-based view. A review and assessment of its critiques, "Journal of Management", vol. 36 no. 1, pp. 349-372.

Kuo T.C., Hanafi J., Sun W.C., Robielos R.A.C. (2016), The effects of national cultural traits on BOP consumer behavior, "Sustainability", vol. 8 no. 3, p. 272.

Landrum N.E. (2014), Defining a base of the pyramid strategy, "International Journal of Business and Emerging Markets", vol. 6 no. 4, pp. 286-297.

Lappeman J., Ransome K., Louw Z. (2019), Not one segment. Using global and local BoP characteristics to model countryspecific consumer profiles, "European Business Review", vol. 31, pp. 317-336.

Lashitew A.A., Narayan S., Rosca E., Bals L. (2021), Creating social value for the 'Base of the Pyramid'. An integrative review and research agenda, "Journal of Business Ethics", pp. 1-22, https://link.springer.com/article/10.1007/s10551-020-04710-2 [10.06.2021].

Leszczyński D. (2015), Emerging varieties of capitalism in transition countries. Literature review, "International Journal of Management and Economics", vol. 48 no. 1, pp. 101-124.

London T., Hart S.L. (2004), Reinventing strategies for emerging markets: beyond the transnational model, "Journal of International Business Studies", vol. 35 no. 5, pp. 350-370.

London T., Hart S.L. (2010), Next generation business strategies for the Base of the Pyramid. New approaches for building mutual value, Pearson Education, India.

Lundvall B.Å. (1999), National business systems and national systems of innovation, "International Studies of Management \& Organization”, vol. 29 no. 2, pp. 60-77.

Marquis C., Raynard M. (2015), Institutional strategies in emerging markets, "Academy of Management Annals", vol. 9 no. 1, pp. 291-335.

Meyer K.E., Estrin S., Bhaumik S.K., Peng M.W. (2009), Institutions, resources, and entry strategies in emerging economies, "Strategic Management Journal", vol. 30, pp. 61-80.

Narayanan V.K., Fahey L. (2005), The relevance of the institutional underpinnings of Porter's five forces framework to emerging economies. An epistemological analysis, "Journal of Management Studies", vol. 42 no. 1, pp. 207-223.

North D.C. (1990), Institutions, institutional change and economic performance, Cambridge University Press, New York.

North D.C. (2005), The contribution of the new institutional economics to an understanding of the transition problem, in: Atkinson A.B. et al., Wider perspectives on global development, Palgrave Macmillan, London, pp. 1-15. 


\section{INTEGRATING GENERAL AND LOCAL CONTEXT-DEPENDENT FACTORS ...}

Omar M., Williams Jr R.L. (2009), Marketing to the Bottom of the Pyramid. Opportunities in emerging markets, "International Journal of Services, Economics and Management", vol. 1 no. 4, pp. 427-446.

Orcos R., Pérez-Aradros B., Blind K. (2018), Why does the diffusion of environmental management standards differ across countries? The role of formal and informal institutions in the adoption of ISO 14001, "Journal of World Business", vol. 53 no. 6, pp. 850-861.

Parmigiani A., Rivera-Santos M. (2015), Sourcing for the Base of the Pyramid. Constructing supply chains to address voids in subsistence markets, "Journal of Operations Management", vol. 33, pp. 6070 .

Pels J., Sheth J.N. (2017), Business models to serve low-income consumers in emerging markets, "Marketing Theory", vol. 17 no. 3, pp. 373-391.

Pitta D., Guesalaga R., Marshall P. (2008), Purchasing power at the Bottom of the Pyramid. Differences across geographic regions and income tiers, "Journal of Consumer Marketing", vol. 25 no. 7, pp. 393-401.

Pizam A., Pine R., Mok C., Shin J.Y. (1997), Nationality vs industry cultures: which has a greater effect on managerial behavior?, "International Journal of Hospitality Management", vol. 16 no. 2, pp. $127-145$.

Porter M.E. (1990), The competitive advantage of nations, "Harvard Business Review", vol. 68 no. 2 , pp. 73-93.

Porter M.E. (2008), The five competitive forces that shape strategy, "Harvard Business Review", vol. 86 no. 1 , pp. $25-40$.

Prahalad C.K. (2006), The fortune at the Bottom of the Pyramid, eradicating poverty through profits, Wharton School Publishing, Upper Saddle River, NJ.

Prahalad C.K., Hart S.L. (2002), The fortune at the Bottom of the Pyramid, "Strategy + Business", vol. 20, pp. 1-13.

Prahalad C.K., Lieberthal K. (1998), The end of corporate imperialism, "Harvard Business Review", vol. 76 no. 4, pp. 6879.

Primus D.J., Robinson-Howe J., Tasca N. (2017), Utilizing PPPs as an alternative to entering BoP markets. Benefits, challenges, and success factors, "Journal of International Business and Economy", vol. 18 no. 2 , pp. $32-59$.

Quist A. (2011), Building a framework for analyzing emerging market business sectors. A case study of the Brazilian soy industry, Master Thesis, University of Groningen.

Raj K., Aithal P.S. (2018), Generating wealth at the Base of the Pyramid. A study using ABCD analysis technique, "International Journal of Computational Research and Development (IJCRD)", vol. 3 no. 1 , pp. 68-76.

Sánchez C.M., Schmid A.S. (2013), Base of the Pyramid success. A relational view, "South Asian Journal of Global Business Research", vol. 2 no. 1, pp. 59-81. 


\section{Maaike Maren BROEKSMA, Bart Jan Willem (Bartjan) PENNINK}

Schuster T., Holtbrügge D. (2012), Market entry of multinational companies in markets at the Bottom of the Pyramid: A learning perspective, "International Business Review", vol. 21 no. 5, pp. 817-830.

Subhan F., Khattak A. (2016), What constitutes the Bottom of the Pyramid (BOP) market, in: Institute of Business Administration International Conference on Marketing (IBA-ICM), Kuala Lumpur.

Tasavori M., Ghauri P., Zaefarian R. (2014), The entry of multinational companies to the base of the pyramid. A network perspective, in: International business and institutions after the financial crisis, Temouri Y., Jones Ch. (eds.), Palgrave Macmillan, London, pp. 39-52.

Van den Ban J. (2009), How to analyze business sectors in emerging markets. A new framework applied to the retail sector in Vietnam, Master Thesis, University of Groningen.

Van den Waeyenberg S., Hens L. (2012), Overcoming institutional distance. Expansion to base-of-thepyramid markets, "Journal of Business Research", vol. 65 no. 12, pp. 1692-1699.

Ver Loren van Themaat T., Schutte C.S., Lutters D., Kennon D. (2013), Designing a framework to design a business model for the 'Bottom of the Pyramid' population, "South African Journal of Industrial Engineering”, vol. 24 no. 3, pp. 190204.

Vinogradov D., Shadrina E., Kokareva L. (2014), Public procurement mechanisms for public-private partnerships, "Journal of Public Procurement", vol. 14 no. 4, pp. 538-566.

Vlados C. (2019), Porter's diamond approaches and the competitiveness web, "International Journal of Business Administration", vol. 10 no. 5, pp. 33-52.

Whitley R. (1998), Internationalization and varieties of capitalism. The limited effects of cross-national coordination of economic activities on the nature of business systems, "Review of International Political Economy", vol. 5 no. 3, pp. 445-481.

Wilkins M., Thelen K., Whitley R., Miller R.M., Martin C.J., Berghahn V.R., Iversen M.J., Herrigel G., Zeitlin J. (2010), "Varieties of capitalism" roundtable, "Business History Review", vol. 84 no. 4, pp. 637-674.

Witt M.A., Redding G. (2013), Asian business systems. Institutional comparison, clusters and implications for varieties of capitalism and business systems theory, "Socio-Economic Review", vol. 11 no. 2 , pp. 265-300.

Wright M., Filatotchev I., Hoskisson R.E., Peng M.W. (2005), Strategy research in emerging economies. Challenging the conventional wisdom, "Journal of Management Studies", vol. 42 no. 1, pp. $1-33$.

Yin R.K. (2003), Case study research. Design and methods, 5th ed., Sage Publications, Thousand Oaks.

Yin R.K. (2018), Case study research and applications. Design and methods, 6th ed., Sage Publications, Thousand Oaks.

Zhu F., Wei Z., Bao Y., Zou S. (2019), Base-of-the-Pyramid (BOP) orientation and firm performance. A strategy tripod view and evidence from China, "International Business Review", vol. 28 no. 6, pp. 101594. 